\title{
CRIME DE TORTURA: DE AUSCHWITZ AOS DIREITOS HUMANOS
}

\section{Antônio Baptista Gonçalves}

\section{RESUMO}

A tortura acompanha a história da humanidade. Não raros são os exemplos de tortura no transcurso do espaço-tempo. No entanto, com o advento das duas Guerras Mundiais a saturação parece ter encontrado seu ápice e um construto de Direitos Humanos foi erigido a fim de modificar as agruras e atrocidades provocadas contra a vida humana. A mudança do paradigma foi a adoção da defesa da dignidade da pessoa humana. Todavia, com tantos séculos de crueldade e terror a tortura não foi imediatamente extirpada da realidade dos governantes. Com isso, o Tribunal Penal Internacional surge como resposta aos crimes dos líderes das Nações. A realidade ainda precisa de reparos, mas a tortura, agora, tem um instrumento eficaz de combate.

Palavras-chave: Tortura. Direitos Humanos. Tribunal Penal Internacional. 


\section{INTRODUÇÃO}

O homem ao longo de sua história teve uma relação intrínseca com a tortura. O uso indiscriminado da força, seja através da violência simbólica, seja da psicológica ou da física remonta a priscas eras.

De tal sorte que ao se relacionar a tortura com os Direitos $\mathrm{Hu}-$ manos importante será uma, ainda que breve, passagem pela história e a localização da tortura no espaço-tempo com os abusos do homem contra seus irmãos e semelhantes.

Essa tortura terá uma tratativa mais específica em nosso estudo com os atos praticados nos campos de concentração da Alemanha Nazista, mais especificamente em Auschiwitz.

E a escolha da Segunda Guerra Mundial e suas atrocidades não foi aleatória, visto que as consequências de seus danos impulsionaram uma resposta da própria humanidade contra os excessos do ser humano. Falamos da chegada dos Direitos Humanos.

Então, inicialmente, localizemos a tortura no espaço tempo para em um momento posterior analisar os acontecimentos de Auschiwitz e como que a própria humanidade reagiu, através dos Direitos Humanos.

\section{EVOLUÇÃO HISTÓRICA DA TORTURA}

A tortura remonta a uma época muito anterior às agruras cometidas na Alemanha nazista.

Desde a antiguidade esta prática já era conhecida e amplamente utilizada. Basta verificar as crenças antigas na formação de sociedades indígenas com suas provas de bravuras, guerras, tortura de tribos vizinhas, etc. $\mathrm{O}$ poder que era representado na figura do chefe da tribo.

Avançando um pouco no tempo temos os desmandos cometidos contra o povo egípcio na construção das pirâmides e da cidade em si.

$\mathrm{Na}$ Grécia, berço da filosofia e da sabedoria, a tortura era utilizada contra escravos e nas palavras de Demóstenes: o testemunho de um escravo obtido através da tortura se revestia de maior credibilidade do que aquele prestado pelo homem livre, sem nenhuma coação.

Em Roma, as barbáries se registraram em somatória continua com o crescimento do Império Romano. O escravo era torturado pela 
impossibilidade de se poder sensibilizá-lo no sentido moral e cívico a dizer a verdade. De que forma é possível negar a tortura com a existência de espetáculos de degradação da vida humana como o Coliseu?

\section{A TORTURA NA IDADE MÉDIA}

Os germanos consideravam determinados delitos extremamente graves, como os atentatórios ao culto e às traições de guerra, nos quais a perda da paz era substituída pela pena de morte, que tinha um caráter de expiação sagrada, cuja reprimenda era infligida, ordinariamente, pelos sacerdotes. Assim, os condenados aos crimes de guerra eram enforcados em árvores, ao passo que os covardes e afeminados eram afogados nos rios, mares e pântanos. Os ladrões de cavalo eram apenados com a reprimenda da lapidação.

\section{DIREITO CANÔNICO}

O movimento de cristianização foi responsável pela tortura indiscriminada dos povos, sem respeito a sua cultura, crença ou costumes. Fenômeno muito praticado através das cruzadas.

Não é possível de se esquecer também o Tribunal do Santo Ofício, no qual os acusados eram julgados pelo crime de heresia. Os livros atentatórios à boa igreja eram queimados, mesmo destino dos hereges. Era formado o período de inquisição da igreja católica, no qual até Galileu teve de se retratar ao afirmar que a Terra era redonda, sob pena de conhecer a fogueira.

O processo investigatório era iniciado até por denúncias anônimas. E no caso do crime de relapso (reincidência após se reconciliar com a Igreja Católica), o acusado era entregue à Justiça secular para a execução da pena de morte, mas não sem antes a pena de tortura a fim de indicar os nomes de seus cúmplices.

\section{A TORTURA NA IDADE MODERNA}


A tortura até o século XIV era enfocada como instrumento processual, com algumas poucas garantias processuais que se perderam a partir do século seguinte.

Com os governos absolutistas os Reis se preocuparam muito mais em assegurar a sua soberania do que com os Direitos Humanos.

A França, que também vivenciou a monarquia absoluta, constituiu um campo fértil para a difusão do processo inquisitivo e, principalmente, da tortura. Embora as cidades francesas aplicassem distintos métodos de tortura, havia torturas que se aplicavam em todo o país, como a tortura da água e a do borzeguim.

A primeira consistia na ingerência de grandes quantidades de água até o médico ordenar uma pausa. A segunda tratava de polaina de couro molhada nos membros inferiores que eram aproximados do fogo e evidentemente encolhiam.

$\mathrm{Na}$ Alemanha, a tortura ingressou como parte do processo inquisitivo ao integrar os estatutos de Worms (1498).

\section{$5 \quad$ A TORTURA NO ILUMINISMO}

Montesquieu em seu célebre livro: O espírito das leis aborda a questão da tortura no capítulo XVII do livro VI.

Inicia sua crítica atacando a fragilidade do legislador na época, que considerava os depoimentos incriminadores de suas testemunhas bastavam, por si só, para a punição de todos os crimes. herege.

Voltaire sofreu com perseguições religiosas por ser acusado de

A tortura estava tão arraigada no subconsciente das pessoas que a adoção da guilhotina não causou espanto ou indignação. E condenou à morte centenas ou milhares de pessoas que conviviam com a tortura psicológica do aguardo da morte em praça pública.

Em meados do século XVIII a tortura é abolida e nos dizeres de FOCAULT (vigiar e punir): Impõe-se o registro de que a abolição da tortura é fruto de um processo final histórico que culminou com a recepção dos ideais ilustrados no Direito Positivo. 


\section{TORTURA NA IDADE CONTEMPORÂNEA}

O século XX, com o advento de duas Guerras Mundiais e com o advento de duas bombas atômicas, não há como se afirmar que a tortura encontrou a extinção.

Há pouco mais de um ano celebraram-se os 60 anos da libertação dos presos em Auschwitz (Oswiecim em polonês) ${ }^{1}$. Tal feito reuniu uma grande comoção mundial. Afinal, construído pelos alemães na Polônia ocupada em 1940, fora responsável pela execução de cerca de 1,5 milhão de pessoas nas câmaras de gás da Alemanha nazista, das quais um milhão eram judias.

As mortes ocorreram pela execução a tiros, pela câmara de gás, de fome ou de doenças em ambos os campos. Para os que não se recordam, havia ainda o campo de concentração de Birkenau, distante apenas 3 km do mais famoso campo de concentração que a história já conheceu.

A política de eliminação de pessoas em massa, adotada pelos nazistas durante a Segunda Guerra Mundial, foi um fenômeno único na história da humanidade. Foram 6 milhões de judeus, entre eles, 1,5 milhão de crianças.

Um momento marcante é o depoimento de Raphael Esrail, sobrevivente do terror: "Tudo era feito para nos desumanizar. Eles nos faziam sentir como vermes. Usávamos um uniforme fino quando a temperatura era menos 20 graus. Não tínhamos casaco, remédio, notícias. A comida era pouca".

\footnotetext{
${ }^{1}$ Hannah Arendt fornece o relato histórico acerca da funcionalidade de Auschwitz: Lendo as atas do julgamento, deve-se ter sempre em mente que Auschwitz fora estabelecido para massacres administrativos que deviam ser executados segundo as regras e regulamentos mais rigorosos. Essas regras e regulamentos tinham sido estipulados pelos assassinos burocratas, e eles pareciam excluir - provavelmente tinham a intenção de excluir - toda iniciativa individual, quer para melhorar a situação, quer para piorá-la. O extermínio de milhões foi planejado para funcionar como uma máquina: os prisioneiros chegando de toda a Europa; as seleções na rampa, e as seleções subsequentes entre aqueles que tinham sido robustos na chegada; a divisão em categorias (todos os idosos, crianças e mães com filhos deviam ser gaseados imediatamente); os experimentos humanos; o sistema dos "prisioneiros de confiança", os capôs e os comandos de prisioneiros que manejavam as instalações de extermínio e detinham posições privilegiadas. Tudo parecia previsto e assim previsível - dia após dia, mês após mês, ano após ano. E, ainda assim, o que resultou dos cálculos burocráticos foi o exato oposto da previsibilidade. Foi uma completa arbitrariedade. ARENDT, Hannah. Responsabilidade e julgamento. Trad. Rosaura Eichenberg. São Paulo: Companhia das letras, 2004. p. 319-320.
} 
Falar em lembrar sobre o holocausto, naturalmente é falar em esquecer, contudo, permeia o receio ao longo do tempo de que os acontecimentos do passado sejam relativizados e possam tornar a ocorrer.

\section{A TORTURA PÓS-SEGUNDA GUERRA MUNDIAL}

Infelizmente, o ocorrido alemão, parece não ter sido suficiente para coibir a prática da tortura. E temos tantos exemplos a citar que ficamos até constrangidos: Ruanda, Bósnia, Iugoslávia, e, recentemente o ataque americano ao Iraque.

O fato é que na Guerra do Iraque, com a suspeita de utilização de supostas armas química, que até o presente momento ainda não foram encontradas, os Estados Unidos invadiram o país e forneceram uma demonstração gratuita ao mundo de como fazer o sangue aparecer.

E, para tanto, em rede nacional o que foi feito? Mostrado ao mundo que os filhos de Saddam Hussein foram torturados até a morte. E para que? Demonstrar supremacia de uma nação sobre outra?

\section{A RESPOSTA DA HUMANIDADE CONTRA A TORTURA: OS DIREITOS HUMANOS}

A Segunda Guerra Mundial, de fato, foi emblemática para que a humanidade quebrasse o paradigma sistemático da tortura como parte da sociedade.

O espólio de mortes de seres humanos de várias nações parece ter aberto os olhos para que os governantes fizessem alguma coisa. Tivemos uma profunda mudança acerca do conceito da vida humana, pois a banalização e o descarte motivados pelas milhares de vidas dizimadas como espólio de Guerra, agora, eram a agenda do dia.

Afinal, com o término da Segunda Guerra Mundial, que perdurou de 1939 a 1945 e deixou um espólio estimado entre 40 a 52 milhões de pessoas mortas ${ }^{2}$ em decorrência dos conflitos.

\footnotetext{
2 Dados da Grande Enciclopédia Larousse Cultural. São Paulo: Nova Cultural, 1998, v. 12, p. 2863.
} 
Não existe afronta maior contra a vida de um ser humano do que uma guerra? $\mathrm{O}$ que diriam as autoridades e os defensores dos direitos humanos por conta da ação humana mais de quarenta milhões de vidas deixaram de existir?

Ademais, somente as mortes já seriam uma justificativa minimamente razoável para uma mudança de paradigma, porém, a Segunda Guerra mundial conteve requintes específicos de crueldade que afrontam a dignidade de qualquer ser humano.

\section{OS DIREITOS HUMANOS - EVOLUÇÃO HISTÓRICA}

A doutrina determina que a primeira geração de direitos humanos tenha seu início com a Independência Americana e a Revolução Francesa ${ }^{3}$. Contudo, é inegável a contribuição de alguns outros atos anteriores. Foi assim com a Magna Carta Inglesa em 1215, e, principalmente, com os atos impulsionados nos séculos XVI e XVII, por advento do movimento conhecido como Iluminismo, quando uma série de atos foram profícuos para o desenvolvimento dos direitos humanos fundamentais através do habeas corpus act, de 1679; o Bill of Rights em 1689. No en-

\footnotetext{
${ }^{3}$ Nilo Odalia: Compreender-se a Revolução Francesa como fundadora dos direitos civis impõe que não nos esqueçamos de que o século XVIII é conhecido como o século do Iluminismo e da Ilustração, por ser o século de Voltaire e Montesquieu, de Kant e Holbach, de Diderot e D'Alembert, de Goethe e Rousseau, de Mozart e Beethoven. Nele se deu, também, a tentativa de transformar as ciências da natureza em ciências da razão e da experimentação. ODALIA, Nilo. A liberdade como meta coletiva. IN PINSKY, Jaime \& PINSKY, Carla Bassanezi (org.). História da cidadania. 5 ed. São Paulo: Contexto, 2010, p. 159.

Somado ao relato de Nilo Odalia temos de considerar os séculos de opressão da Igreja Católica em decorrência da Inquisição, a dominação do Clero e da Nobreza sobre a esmagadora maioria da população francesa denominada de Terceiro Estado. No entanto, o Terceiro Estado, ao qual se situava a Burguesia, era explorado e perdia riquezas e territórios para o Clero, especialmente, e para a nobreza. Em toda essa conjuntura histórica era de se esperar que a Revolução fosse apenas uma questão de tempo. E ainda, com a influência dos ideais propostos pela abertura de Napoleão Bonaparte o avanço em defesa das liberdades e a cisão com a tirania e com a submissão eram inevitáveis.

E o marco dessa Revolução foi a consequência direta produzida ao longo do globo, pois, se não foi o embrião dos direitos fundamentais, foi, sem dúvida, a sua mola propulsora.
} 
tanto é necessário compreender o contexto histórico para concordar com a doutrina ${ }^{4}$.

Afinal, se a concessão de um direito dependia de um soberano, então o direito não era universal e a disposição do homem, logo, ao ser atrelado a vontade de outrem se tornava restrito, realidade essa, que realmente, somente se modificou com as Declarações Americana de 1776 e Francesa de 1789.

Todavia, a quebra de paradigma se iniciou com o iluminismo, pois esse movimento foi o responsável por impulsionar novamente os ideários dos direitos humanos, que resultaram nos processos de conflitos na França e nos Estados Unidos, que culminaram com a Revolução Francesa e a Independência norte americana, respectivamente e que determinaram o surgimento da primeira geração dos Direitos Humanos ${ }^{5}$.

Todos esses atos foram importantes para desenvolver o conceito de liberdade, fraternidade e igualdade entre todos os homens. Contudo, os conflitos e, especialmente, as mortes impulsionaram uma necessidade de buscar a valoração do próprio homem. E a Primeira Guerra Mundial que

\footnotetext{
${ }^{4} \mathrm{Na}$ verdade, Norberto Bobbio elucida a importância dos movimentos anteriores à Revolução Francesa e explica os motivos de não serem considerados como marcos para os direitos humanos: A relação tradicional entre direitos dos governantes e obrigações dos súditos é invertida completamente. Até mesmo nas chamadas cartas de direitos que precederam as de 1776 na América e a de 1789 na França, desde a Magna Charta até o Bill of Rights de 1689, os direitos ou as liberdades não eram concedidos ou concertados, devendo parecer - mesmo que fossem resultado de um pacto entre súditos e soberano - como um ato unilateral deste último. $\mathrm{O}$ que equivale dizer que, sem a concessão do soberano, o súdito jamais teria tido qualquer direito. Não é diferente o que ocorrerá no século XIX: quando surgem as monarquias constitucionais, afirma-se que as Constituições foram octroyées pelos soberanos. $\mathrm{O}$ fato de que essas Constituições fossem a consequência de um conflito entre rei e súditos, concluído com um pacto, não devia cancelar a imagem sacralizada do poder, para a qual os cidadãos obtêm é sempre o resultado de uma graciosa concessão do príncipe. As Declarações de Direito estavam destinadas a inverter essa imagem. E, com efeito, pouco a pouco lograram invertê-la. Hoje, o próprio conceito de democracia é inseparável do conceito de direitos do homem. BOBBIO, Norberto. A Era dos Direitos. Rio de Janeiro: Elsevier, 2004, p. 114.

${ }^{5}$ Fábio Konder Comparato afirma: "O artigo I da Declaração que "o bom povo da Virgínia" tornou pública, em 16 de junho de 1776, constitui o registro de nascimento dos direitos humanos na História. COMPARATO, Fábio Konder. A afirmação histórica dos
} Direitos Humanos. 3 Ed. São Paulo: Saraiva, 2003, p. 49. 
ocorreu entre 1914 e 1918, com um saldo negativo de 9 milhões de mortos $^{6}$, acelerou ainda mais o processo.

No entanto, como que as Nações se organizaram para discutir e desenvolver um contrarremédio às agruras trazidas pelas guerras? A resposta a essa indagação, a nosso ver, representou a evolução concreta dos direitos humanos para a defesa do cidadão.

\section{OS DIREITOS HUMANOS PÓS I E II GUERRAS MUNDIAIS}

Os Direitos Humanos conheceram uma nova fase com o final da Segunda Guerra mundial, em um movimento que se iniciou com as guerras francesas e sua Declaração dos Direitos do Homem em 1789.

O marco histórico é a presença na Declaração Francesa de 1789 o artigo $2^{\circ}$ :

A finalidade de toda associação política é a preservação dos direitos naturais e imprescritíveis do homem. Esses direitos são a liberdade, a prosperidade, a segurança e a resistência à opressão. ${ }^{7}$

Com o término das guerras e a perda inestimável de milhões de vidas, o primeiro grande ato em busca da defesa dos direitos humanos foi a criação em 26 de junho de 1945, em São Francisco de um órgão que iria representar os cinquenta e um países signatários e proteger os cidadãos, suas relações, liberdades, etc., nascia assim a Organização das Nações Unidas (ONU).

Apenas três anos após a sua criação, em 1948, a ONU aprovou a Declaração Universal de Direitos do $\mathrm{Homem}^{8}$, que notadamente foi

\footnotetext{
${ }^{6}$ Dados da Grande Enciclopédia Larousse Cultural. São Paulo: Nova Cultural, 1998, v. 12, p. 2859.

${ }^{7}$ Fonte: http://www.senat.fr/lng/pt/declaration_droits_homme.html, acesso em 3 de fevereiro de 2011.

${ }^{8}$ Norberto Bobbio afirma que: A Declaração Universal dos Direitos do Homem pode ser acolhida como a maior prova histórica até hoje dada do consensus omnium gentium sobre um determinado sistema de valores. Os velhos jusnaturalistas desconfiavam - e não estavam inteiramente errados - do consenso geral como fundamento do direito, já que esse
} 
influenciada pela Declaração de 1789, mas lapidada pelas agruras dos acontecimentos históricos já referidos.

O preâmbulo já possui os elementos norteadores do que viriam a se traduzir em um novo conceito de Direitos humanos ao justificar os anseios sociais das pessoas comuns ${ }^{9}$.

José Lindgren Alves já apontava as semelhanças:

Seus postulados fundamentais, que remontam à Revolução Francesa, são a liberdade, a igualdade e a fraternidade, expressos na formulação do Artigo $1^{\circ}$ de que "todas as pessoas nascem livres e iguais em dignidade e direitos", devendo agir reciprocamente "com espírito de fraternidade". Desses postulados decorre o princípio da não discriminação por motivo de raça, cor sexo, língua, religião, opiniões, origem nacional ou social, riqueza, nascimento ou qualquer outra condição, inclusive a situação política, jurídica ou nível de autonomia do território a que pertençam às pessoas explicitado no Artigo $2^{\circ 10}$.

consenso era difícil de comprovar. Seria necessário buscar sua expressão documental através da inquieta e obscura história das nações, como tentaria fazê-lo Giambattista Vico. Mas agora esse documento existe: foi aprovado por 48 Estados, em 10 de dezembro de 1948, na Assembleia Geral das Nações Unidas; e, a partir de então, foi acolhido como inspiração e orientação no processo de crescimento de toda a comunidade internacional no sentido de uma comunidade não só de Estados, mas de indivíduos livres e iguais. BOBBIO, Norberto. A Era dos Direitos. Rio de Janeiro: Elsevier, 2004, p. 47.

${ }^{9}$ Considerando que o reconhecimento da dignidade inerente a todos os membros da família humana e de seus direitos iguais e inalienáveis é o fundamento da liberdade, justiça, e da paz no mundo,

Considerando que o desprezo a o desrespeito pelos direitos humanos resultou em atos bárbaros que ultrajaram a consciência da Humanidade e que o advento de um mundo no qual os seres humanos gozem de liberdade de expressão e de crença e da liberdade de viverem a salvo do temor e da necessidade foi proclamado como a mais alta aspiração do homem comum. (Duas primeiras partes do preâmbulo). ALVES, José Augusto Lindgren.

A arquitetura internacional dos direitos humanos. São Paulo: FTD, 1997, p. 49.

${ }^{10}$ ALVES, José Augusto Lindgren. A arquitetura internacional dos direitos humanos. São Paulo: FTD, 1997, p. 27. 
Com a Declaração Universal dos Direitos do Homem ${ }^{11}$, de 1948, o homem, ou melhor, a dignidade da pessoa humana passou a ser a principal preocupação e o alvo máximo de proteção.

E, também, um novo marco histórico fundamental, pela primeira vez fora criado um documento universalmente aceito pela maioria das pessoas, através da ratificação de seus governos, um conjunto de regramentos e comportamentos sociais criados pelo próprio homem ${ }^{12}$.

Sempre a humanidade reagiu positivamente após um grande mal causado pelo próprio homem, foi assim com a Convenção de Viena, após o final da I Guerra Mundial e, foi assim, com a criação de um organismo transnacional, independente responsável por regular as relações sociais e humanitárias entre os seus Estados-Membros, papel esse que passou a ser desenvolvido pela Organização das Nações Unidas a partir de 1945.

Após a Declaração Universal dos Direitos do Homem, de 1948, uma série de atos, resoluções e medidas foram desenvolvidas para proteger o direito das minorias e, acima disso, garantir a igualdade de direitos, independentemente da orientação política, sexual ou religiosa e, evitar que a tortura fosse cometida livremente como feita no passado.

\section{OS INSTRUMENTOS PROTETIVOS DE DIREITOS HUMANOS SOBRE A TORTURA}

Flávia Piovesan ensina que o moderno Direito Internacional dos Direitos Humanos é um fenômeno do pós-guerra. Seu desenvolvimento

\footnotetext{
${ }^{11}$ Norberto Bobbio tinha dúvidas se a humanidade tinha consciência da grandeza do que a Declaração Universal dos Direitos do Homem representava para a própria história: Não sei se tem consciência de até que ponto a Declaração Universal representa um fato novo na história, na medida em que, pela primeira vez, um sistema de princípios fundamentais da conduta humana foi livre e expressamente aceito, através de seus respectivos governos, pela maioria dos homens que vivem na Terra. BOBBIO, Norberto. A era dos direitos. Rio de Janeiro: Elsevier, 2004, p. 47.

${ }^{12}$ Norberto Bobbio: Somente depois da Declaração Universal é que podemos ter a certeza histórica de que a humanidade - toda a humanidade - partilha alguns valores comuns; e podemos, finalmente, crer na universalidade dos valores, no único sentido em que tal crença é historicamente legítima, ou seja, no sentido em que universal significa não algo dado objetivamente, mas algo subjetivamente acolhido pelo universo dos homens. BOBBIO, Norberto. A era dos direitos. Rio de Janeiro: Elsevier, 2004, p. 48.
} 
pode ser atribuído às monstruosas violações de direitos humanos da era Hitler e à crença de que parte destas violações poderiam ser prevenidas se um efetivo sistema de proteção internacional de direitos humanos existis$\mathrm{se}^{13}$.

Então, cabe-nos apresentar o sistema protetivo que fora criado quando do surgimento dos Direitos Humanos e, em especial, após a criação da Organização das Nações Unidas - ONU.

O Pacto de San José da Costa Rica veda expressamente, em seu artigo 27 eventual suspensão de garantias seja aplicável à permissibilidade de um individuo ser torturado.

A já citada Convenção de 1984 tem um dispositivo expresso sobre o tema:

Artigo $2^{\circ}, \S 2^{\circ}$. Em nenhum caso poderão invocar-se circunstâncias excepcionais, como ameaça ou estado de guerra, instabilidade política interna ou qualquer outra emergência pública, como justificação para a tortura.

E, não poderíamos deixar de citar, a Convenção Interamericana de Direitos Humanos:

Art. $5^{\circ}$. Não se invocará nem admitirá como justificativa do delito de tortura a existência de circunstâncias tais como o estado de guerra, a ameaça de guerra, o estado de sítio ou de emergência, a comoção ou conflito interno, a suspensão das garantias constitucionais, a instabilidade política interna, ou de outras emergências ou calamidades públicas. Nem a periculosidade do detido ou condenado, nem a insegurança do estabelecimento carcerário ou penitenciário podem justificar a tortura.

13 PIOVESAN, Flávia. Direitos humanos e o direito constitucional internacional. 3 ed. São Paulo: Max Limonad, 1997. p. 139. 
A definição enciclopédica sobre a tortura: 1 . Suplício violento a que se submete alguém- 2. Fig. Sofrimento moral intenso; angústia - 3 . Tortuosidade ${ }^{14}$.

Preferimos a do artigo I da Convenção contra a Tortura e Outras Penas ou Tratamentos Cruéis, Desumanos ou Degradantes:

\begin{abstract}
Artigo I
Para os fins da presente Convenção, o termo "tortura" significa qualquer ato por meio do qual uma dor ou sofrimentos agudos, físicos ou mentais, são intencionalmente causados a uma pessoa com os fins de obter dela ou de uma terceira pessoa informações ou confissões, punir por um ato que ela ou uma terceira pessoa cometeu ou se suspeita que tenha cometido, intimidar ou pressionar essa ou uma terceira pessoa, ou por qualquer outro motivo baseado em alguma forma de discriminação, desde que essa dor ou esses sofrimentos sejam infligidos por um agente público ou qualquer outra pessoa agindo a título oficial, por sua instigação ou com o seu consentimento expresso ou tácito. O termo não compreende a dor e os sofrimentos resultantes unicamente de sanções legítimas, inerentes a essas sanções ou por delas ocasionados ${ }^{15}$.
\end{abstract}

Mais incisiva, a Convenção Interamericana para prevenir e punir a tortura dispôs terminantemente, no seu preâmbulo, que a tortura e os demais tratamentos já referidos "consagrados na Carta da Organização dos Estados Americanos e na Carta das Nações Unidas, e são violatórios dos direitos humanos e liberdades fundamentais...".

Antes cronologicamente de ambas, devemos citar também, a não menos importante, Declaração Universal dos Direitos Humanos de 1948, que reza em seu artigo V:

\footnotetext{
${ }^{14}$ Grande Enciclopédia Larousse Cultural, v. 23, p. 5.718.

${ }^{15}$ Convenção adotada e aberta para assinatura, ratificação e adesão pela Resolução 39/46 da Assembleia Geral, de 10 de dezembro de 1984.
} 
Ninguém será submetido a tortura, nem a tratamento ou castigo cruel, desumano ou degradante.

\section{OS "ENSINAMENTOS" DE AUSCHIWITZ PARA A HUMANIDADE ACERCA DA TORTURA}

E, nesses termos Auschwitz foi muito importante. O campo, enquanto acontecimento é singular, porque ali se alcançou no homem um nível de maldade até então desconhecido, e, por isso, originou uma nova figura jurídica para qualificar o acontecido: crimes contra a humanidade.

Em ultima instância é o crime contra a pessoa humana individual, praticado através da tortura nos limites extremos: física, moral e psicológica.

Segundo relatos próprios ${ }^{16}$, o bloco 11 de Auschwitz era a prisão dentro da prisão e ali se aplicavam castigos ainda mais cruéis. Alguns deles consistiam em confinamento por vários dias em uma cela muito pequena, até mesmo para sentar-se. Outros eram executados, pendurados ou deixados para morrer de fome.

A própria entrada do campo já é uma tortura psicológica camuflada: "Arbeit Macht Frei" (O trabalho conduz à liberdade). E por que se tratava de uma tortura? Devido ao fato de semear no inconsciente do preso, de que se esse trabalhasse até a exaustão poderia ser libertado.

Uma grande falácia, pois, na verdade, seu "prêmio", seria a tortura física culminando com a morte.

\section{A TORTURA CONTINUA MESMO APÓS CRIAÇÃO DO SISTEMA PROTETIVO DE DIREITOS HUMANOS}

Infelizmente, o ocorrido alemão, mesmo com o sistema de Direitos Humanos, parece não ter sido suficiente para coibir a prática da tortura. E temos alguns exemplos: Ruanda, Bósnia, Iugoslávia, e, recentemente o ataque americano ao Iraque.

\footnotetext{
16 Visitamos os campos de concentração em janeiro de 2004.
} 
A discussão não circunda em torno dos motivos que resultam nas mortes, mas sim, que uma única morte, em tais condições, de um ser humano, deveria ser motivo de profunda vergonha para toda a humanidade.

Adolf Hitler nos mostrou que o holocausto era apenas a ponta de um profundo iceberg. Afinal, as escusas foram várias e frequentes para justificar as atrocidades ao longo do tempo.

Os governantes supremos sempre desenvolvem uma justificativa de "força maior" como uma mera desculpa social para perpetrar o terror que culmina com suas ordens.

Quantos foram massacrados em Ruanda? E que providências foram tomadas?

Um exemplo mais recente: a guerra do Iraque. E aqui deixamos claro que o nosso posicionamento é demonstrar e combater a tortura e não fazer apologia a este ou aquele governante.

O fato é que na Guerra do Iraque, com a suspeita de utilização de supostas armas químicas, o que depois foi comprovado que nunca existiram, os Estados Unidos invadiram o país e forneceram uma demonstração gratuita ao mundo de como fazer o sangue aparecer.

Os fatos presenciados pelos jornalistas naquele país registraram a crueldade dos soldados em busca de um alvo específico: o governante supremo, o ditador.

E, para tanto, em rede nacional o que foi feito? Mostrado ao mundo que os filhos de Saddam Hussein foram torturados até a morte. E para que? Demonstrar supremacia de uma nação sobre outra? O cerne da questão não é a inocência deste ou daquele, mas sim a prática da tortura como degredo social.

Os homens da antiguidade eram tão criticados por seus métodos prosaicos e antiquados, entretanto, o que faz o tão evoluído ser superior atual senão pior do que seus antepassados.

As técnicas de tortura são amplamente conhecidas principalmente na Idade Média. Não obstante uma pergunta permeia nosso inconsciente: em que época estamos mesmo?

A resposta será no século XXI, no suprassumo da modernidade, no qual a tecnologia está avançadíssima, praticamente tornou-se impossível acompanhar os avanços da informática. 
E de que ajudou todo esse conhecimento na formação das pessoas enquanto indivíduos? NADA!

\section{O TRIBUNAL PENAL INTERNACIONAL E A RESPONSABILIZAÇÃO DOS TORTURADORES}

A cada dia acompanhamos novas notícias de torturas. E não pense o leitor que por ventura tenhamos esquecido da existência de uma legislação internacional que coíbe a tortura.

E muito menos, da existência de um Tribunal Penal Internacional que fora criado justamente para combater os crimes contra a humanidade. Então tudo parece estar correto.

Afinal temos a legislação e o órgão competente para aplicá-la, não é mesmo? Ledo engano. Com todo o aparato legislativo à disposição ainda se vê diariamente a tortura sendo praticada de forma impune.

E não pensem os senhores que a legislação sobre o combate à tortura internacional não previa a competência de julgar os crimes, antes da criação do Tribunal Penal Internacional.

Prova cabal de tal assertiva é a Convenção Europeia, elaborada em 4 de janeiro de 1950, em Roma, pelo Conselho Europeu. Segundo a qual, além de salvaguardar os direitos daqueles submetidos a eventual prisão processual ou penal, aquela convenção criou a Comissão Europeia de Direitos Humanos e o Tribunal Europeu de Direitos Humanos, encarregada de fiscalizar o respeito aos direitos assegurados em tal normação, bem como o julgamento de eventual violação de seus preceitos por algum Estado signatário, constituindo tal instrumento um importante "reconhecimento do indivíduo como sujeito de direitos internacional, no que tange à proteção dos direitos humanos"17.

Se existe um regramento a questão que surge é qual o motivo de sua não aplicabilidade?

A resposta é inócua, apesar de verdadeira, o fato é que os países soberanos signatários destes Tratados e Convenções contra a tortura conseguem obter uma brecha legislativa para justificar tais atrocidades.

17 COMPARATO, Fábio Konder. A afirmação histórica dos direitos humanos. São Paulo: Saraiva, 1999, p. 240. 
Além disso, o Tribunal Penal Internacional teve seu funcionamento relativamente há pouco tempo, e não se pode esperar que todos os crimes sejam resolvidos do dia para a noite.

Alguns podem pensar que a possibilidade de punição é inversamente proporcional ao poder que o país possui no âmbito global.

Na prática, nem está resposta se reputa verdadeira, visto que o ex-presidente do Chile, o Sr. Pinochet conseguiu, com sucesso, se livrar da responsabilidade pelos crimes cometidos contra os chilenos, e dentre os muitos, é claro, a prática de tortura.

Apesar disso, ainda existem nações que buscam soluções, alternativas para o fim da tortura.

Os próprios governantes das Nações árabes formularam um projeto de convenção em 1989, destinado a combater a tortura e demais tratos desumanos e degradantes, cujo documento foi elaborado pelo Instituto Superior Internacional de Ciências Criminais de Siracusa, Itália, encontrando-se em fase de aprovação pelos chefes de Estado árabes e, igualmente, pela Liga de Estados Árabes ${ }^{18}$.

O mencionado instrumento jurídico traz um importante avanço na discussão acerca do tema em seu artigo $3^{\circ}$, visto que estabelece que a culpabilidade do executor da tortura seja a mesma daquele que a ordenou ou a aprovou, ou, mesmo sabendo que ela iria ser praticada ou já se estava desencadeando, omitiu-se, quando, devido a suas funções, poderia têla impedido ou cessado a sua execução.

Vicente Grima Lizandra sugere que a não punibilidade dos crimes de tortura se deve a uma questão eminentemente cultural:

Não se pode desconsiderar a percuciente lição de que: "o fenômeno da tortura, pois, está presente de um modo ou de outro em todos os Estados do mundo. Em alguns é um método ou sistema de governo. Em outros é praticada de modo mais ou menos esporádico e mais ou menos tolerada por governos, ainda que desprovido de caráter sistemático e generalizado. E, em outros, enfim, somente ocorre em contadas e excepcionais

${ }^{18}$ GONZÁLES GONZÁLES, Rossana. El control internacional de la prohibicíon de la tortura y otros tratos o penas inhumanos y degradantes. Granada: Universidad de Granada, 1998, p. 51. 
ocasiões, o que não exclui que estejam ameaçados pela possibilidade de praticá-la, sobretudo em casos de conflitos internos ou externos graves ${ }^{19}$.

Nesse esteio segue Jesus Barquin Sanz:

De outra feita é forçoso reconhecer que as Nações não ficarão livres dos arautos da utilidade da tortura, os quais merecem total repúdio, vez que esta representa, acima de tudo, a negação da própria pilastra do sistema democrático, que enfoca "o indivíduo como fim em si mesmo, cuja dignidade e humanidade não podem sacrificar-se em favor de pretendidos interesses superiores pela simples razão de que não há maior interesse que a salvaguarda da integridade moral das pessoas ${ }^{20}$.

Nesse ponto é que queremos aprofundar a análise. É muito mais conveniente para um governante soberano utilizar-se de técnicas sabidamente proibidas e cruéis para obter os resultados almejados, do que os ditos procedimentos burocráticos que demorariam uma infinidade e poderia conduzir a lugar algum.

Um dos argumentos para justificar, ainda que de forma não escusável, a prática da tortura reputa no fato de representar um castigo à vítima ou a uma terceira pessoa por um fato que cometeu ou se suspeite de que o tenha cometido. A hipótese em exame contempla a inflação de suplício, com o fim único de punir o torturado, citando-se, como exemplo, a tortura praticada contra um presidiário, pelo fato de ter ele tentado empreender fuga ou participado de algum motim ${ }^{21}$.

Reforçamos a tese anterior, nenhuma justificativa é plausível o suficiente para sustentar uma atrocidade contra a integridade física de quem quer que seja.

${ }^{19}$ GRIMA LIZANDRA, Vicente. Los delitos de tortura y de tratos degradantes por funcionários públicos. Valencia: Tirant lo Blanch, 1998, p. 42.

${ }^{20}$ SANZ, Jesus Barquin. Los delitos de tortura y tratos in humanos o degradantes. Madrid: Edersa, 1992, p. 10.

${ }^{21}$ RODRIGUEZ MESA, Maria José. Tortura y otros delitos contra la integridad moral cometidos por funcionários públicos. Granada: Comares, 2000, p. 64. 
Inclusive, a proteção deve partir das nações sobre os seus habitantes.

A Convenção das Nações Unidas contra a Tortura afirma que:

Cada Estado Membro assegurará que todos os atos de tortura sejam considerados crimes nos termos de sua legislação penal. $\mathrm{O}$ mesmo aplicar-se-á à tentativa de tortura e a todo ato, de qualquer pessoa, que constitua cumplicidade ou participação na tortura. Cada Estado Membro punirá esses crimes com penas adequadas que levem em conta a sua gravidade $^{22}$.

A tortura constitui fenômeno degradante da dignidade da pessoa humana. Apesar de sua proibição pela norma internacional e interna, essa prática permanece no cenário atual. A erradicação desse mal depende, sobremaneira, de se dar efetividade aos instrumentos legais vigentes, valendo salientar a necessidade de qualificação dos profissionais do direito $^{23}$.

\section{OS AVANCOS NO COMBATE DA TORTURA: A PROTEÇÃO DA DIGNIDADE DA PESSOA HUMANA}

Intrigante, em 27 de janeiro de 2005, Chefes de Estado e de governo de 40 países, entre eles os presidentes da Polônia, de Israel, da Rússia, da Alemanha e da França se reuniram para celebrar o fim de um passado escabroso e sombrio ao qual nenhum deles gostaria de reviver, como muitos de seus antepassados foram obrigados a fazê-lo.

Ao mesmo tempo, que celebram o fim do horror, as mesmas autoridades não conseguem, além do plano ideal, como diria Platão chegar a um consenso de igualdade, liberdade e fraternidade, no qual o homem pode finalmente ser livre.

\footnotetext{
${ }^{22}$ Artigo 4 da Convenção das Nações Unidas Contra a Tortura e Outros Tratamentos ou Penas Cruéis, Desumanos ou Degradantes, 1984.

${ }^{23}$ Peter Collecott, Embaixador do Reino Unido no Brasil, Prefácio do livro Combate à tortura.
} 
Pontes de Miranda nos brinda com um eloquente pensamento, segundo o qual almas novas são necessárias para um mundo novo:

Os homens do Estado que pregavam paz e armavam os povos, crendo que a carnificina alivia os problemas dos sem-trabalho, esses homens já são conhecidos. Todos os conhecem. Os povos deixarse-ão guiar dificilmente pelos políticos e diplomatas fazedores de guerras, ou de empréstimos. Caíram condições sociais que acreditávamos permanentes, se não eternas. Desbotaram-se valores históricos, que todos tinham por firmes. Mas tanto os reacionários quanto os impacientes reduzem tudo a um problema de causas econômicas e de força. $\mathrm{O}$ espírito mesmo mudou. $\mathrm{O}$ que dizemos princípio de dissolução é apenas princípio de solução.

Querem persistir, de todo, no meio de figuras de cera de cultura caduca; ou desbaratar tudo, como desesperados. Num e noutro caso, incapacidade de ver linhas novas que se desenham no fundo da vida material e nos borbulhamentos da vida espiritual. Pedem mais ciência e mais técnica para as realizações industriais. Nenhuma ciência, nenhuma técnica para os problemas do homem. Só se pensa na força.

¿Que construiu a Força? Nas coisas e com as coisas, muito. Nos espíritos e com os espíritos, quase $\operatorname{nada}^{24}$.

Esse pensamento se alia ao legado, ainda que maculado, que Adolf Hitler deixou à humanidade. As pessoas se preocupam demasiadamente em evoluir, em avançar, progredir numa velocidade cada vez maior, custe o que custar.

Mesmo que para isso seja necessário o uso da força para que a nação acompanhe o pensamento de seu governante. Exatamente neste instante, há o esquecimento do mais precioso: a vida humana.

${ }^{24}$ MIRANDA, Pontes de. Democracia, liberdade, igualdade. Campinas: Bookseller, 2002. p. 70-71. 
Foi exatamente o que o Governante da Alemanha nazista fez, utilizou-se da força em limites extremos para garantir uma soberania estatal, sem em momento algum levar em consideração a vida humana, que ficou preservada apenas à raça ariana, a dita "pura" e merecedora de um futuro promissor.

A vida humana é trocada em detrimento do progresso. Que avanço pode ter uma sociedade que se diz cada vez mais globalizada a partir do momento que os valores individuais não são respeitados e o direito à vida deixa de ser uma obrigação para dar vez ao "bem maior": Estado.

E quem determina que o Estado seja maior, ou melhor, do que a vida de um inocente? Perante as leis de Deus somos todos iguais. Segundo as leis francesas, que foram as inspiradoras da modernidade os três princípios basilares são igualdade, liberdade e fraternidade.

Quando o direito irrefutável à liberdade e à igualdade prevista em todas as Constituições Democráticas podem ser tolhidas em prol de um bem coletivo denominado progresso que fulmina aquilo que deveria erigir.

Afinal, o que seria o sacrifício de uma vida se todo um Estado encontrar a paz? E se tal governante fosse destinado a se confrontar com o dilema mais doloroso de todos: a tal vida a ser torturada e encerrada seria a de suas próprias veias, ou seja, de um de seus descendentes?

Nessa hora, a nação estaria em primeiro plano, ou o governante supremo refutar-se-ia de cumprir com o seu "dever" profissional para proteger o seu próprio legado?

Vamos exemplificar a questão hipoteticamente. Existe um terrorista que faz ataques contínuos e reiterados a uma das mais poderosas nações do mundo. Sua identidade é desconhecida. E após incansáveis buscas e rastreamentos criminoso é aprisionado. Entretanto, ele não é o mandante, mas sim o segundo em comando, o real mandante, segue foragido. E para a surpresa e espanto, o homem preso é o filho do Presidente.

Será esse torturado de todas as formas possíveis e imaginárias, como seria uma pessoa desconhecida, até que revelasse quem ameaça a segurança nacional?

A resposta é uníssona: não. Por uma questão simplista, nenhum pai tortura e mata o próprio filho, por pior que possa vir a ser. Neste momento não existe mais o presidente e o país, mas sim um pai e um filho. 
Pode até ser que este fique preso indefinidamente, mas não será maltratado, não terá sua integridade física, moral e psicológica violada.

E o que difere essa pessoa de um ilustre desconhecido? Nada. Porque os direitos de ser um cidadão deveriam ser os mesmos. Todavia, "os bens da nação" são muito mais importantes do que a integridade de um reles mortal.

Há uma degradação inerente e inevitável da dignidade humana da vítima de sua condição humana, privando-se da liberdade, de forma que essa se transfigura num objeto, ficando à mercê do torturador.

Como já salientamos em momentos anteriores não existe uma justificativa legal para a prática da tortura, e a prova disso verifica-se no Pacto Internacional dos Direitos Civis e Políticos, que, apesar de permitir no seu artigo $4^{\circ}$, que os Estados-partes possam, em situação excepcional, derrogar as obrigações decorrentes do aludido instrumento, ressalva, no $\S 2^{\circ}$ do mesmo artigo, que o permissivo em referência não alcança, dentre outros, $\mathrm{o}$ artigo $7^{\circ}$, que trata da proibição da tortura.

$\mathrm{Na}$ mesma linha temos a Convenção Europeia de Direitos $\mathrm{Hu}-$ manos, através de dispositivo ínsito no artigo $15, \S 2^{\circ}$, não permite a derrogação nem a suspensão do artigo $3^{\circ}$, que reconhece o direito da pessoa humana de não ser torturada nem mesmo em caso de guerra ou de qualquer outra instabilidade política que ameace a Nação.

O Pacto de San José da Costa Rica veda expressamente, em seu artigo 27 eventual suspensão de garantias seja aplicável à permissibilidade de um indivíduo ser torturado.

A já citada Convenção de 1984 tem um dispositivo expresso sobre o tema:

Artigo $2^{\circ}, \S 2^{\circ}$. Em nenhum caso poderão invocar-se circunstâncias excepcionais, como ameaça ou estado de guerra, instabilidade política interna ou qualquer outra emergência pública, como justificação para a tortura.

E, não poderíamos deixar de citar, a Convenção Interamericana:

Art. $5^{\circ}$. Não se invocará nem admitirá como justificativa do delito de tortura a existência de 
circunstâncias tais como o estado de guerra, a ameaça de guerra, o estado de sítio ou de emergência, a comoção ou conflito interno, a suspensão das garantias constitucionais, a instabilidade política interna, ou de outras emergências ou calamidades públicas. Nem a periculosidade do detido ou condenado, nem a insegurança do estabelecimento carcerário ou penitenciário podem justificar a tortura.

E, recentemente, com o Estatuto de Roma, que entrou em vigor em 1 de julho de 2002, com a instituição de um Tribunal Penal Internacional, que abraça em seu estatuto a competência material que abrange os crimes mais graves de transcendência para a comunidade internacional, alcançando, por conseguinte, os crimes de genocídio, os crimes de lesa humanidade, os crimes de guerra e os delitos de agressão.

Deste diploma o que nos interesse é o artigo $7^{\circ}$ :

Entende-se por 'crime contra a humanidade' qualquer um dos seguintes atos quando praticados como parte de um ataque generalizado ou sistemático contra uma população civil e com conhecimento de tal ataque: a) homicídio; b) extermínio); c) escravidão; d) deportação ou transferências forçadas de populações; e) encarceramento ou outra privação grave de liberdade física em violação às normas fundamentais de Direito internacional; f) tortura; g) estupro, escravidão sexual, prostituição forçada ou outros abusos sexuais de gravidade comparável; $\mathrm{h}$ ) perseguição de um grupo ou coletividade com identidade própria, fundada em motivos políticos, raciais, nacionais, étnicos, culturais, religiosos, de gênero, como definido no $\$ 3^{\circ}$, ou outros motivos universalmente reconhecidos como inaceitáveis conforme o Direito internacional, em conexão com qualquer ato mencionado no presente parágrafo ou com qualquer crime da jurisdição deste Tribunal; i) desaparecimento forçado de pessoas; $j$ ) o crime de apartheid; k) outros atos desumanos de caráter similar, que causem, intencionalmente grande 
sofrimento ou atentem, gravemente, contra a integridade física ou a saúde mental ou física.

Fauzi Hassan Choukr:

Tortura' entende-se infligir intencionalmente dores ou sofrimentos graves, físicos, ou mentais, a um indivíduo que o acusado tenha sob a sua custódia ou controle; não se considerará como tortura dores ou sofrimentos que sejam consequência unicamente de sanções lícitas ou que sejam inerentes a tais sanções ou dela decorram ${ }^{25}$.

Kant analisou a dignidade com grande cientificidade, enfocando-se sob dois aspectos: consistente o primeiro, em considerar o homem como um fim em si mesmo e que, portanto, não pode ser utilizado como simples meio instrumental, como uma coisa; quanto ao segundo, deixou transparecer que a dignidade expressa o reconhecimento da liberdade e autonomia do ser humano ${ }^{26}$.

Impossível falar em tortura sem citar Cesare Beccaria: não haverá liberdade sempre que as leis permitirem que, em certas circunstâncias, o homem deixe de ser pessoa e se torne coisa ${ }^{27}$.

Tal argumento encontra consonância com os pensamentos já citados por Pontes de Miranda, a liberdade do homem não pode ser confundida e muito menos perdida. Do contrário, será considerado como um mero objeto de decoração.

Exatamente por isso que a integridade do homem vale acima de qualquer vontade coletiva, ou até mesmo supranacional. $\mathrm{O}$ indivíduo deve ser considerado em si mesmo para depois se formar uma sociedade, e ainda mais avançada uma nação.

Todos são idênticos em privilégios e obrigações, constitucionalmente garantidos. Na tortura, sedimenta-se, portanto, um atentado à

25 CHOUKR, Fauzi Hassan; Kai Ambos. Tribunal penal internacional. São Paulo: Editora Revista dos Tribunais, 2000. p. 390-391.

${ }^{26}$ KANT, Immanuel. Fundamentação da metafísica dos costumes. Trad. Paulo Quintela. Lisboa: Edições 70, 2001. p. 68-71.

${ }^{27}$ BECCARIA, Cesare. Dos delitos e das penas. Trad. J. Cretella Jr. E Agnes Cretella. 2. ed. Ver. São Paulo: Revista dos Tribunais, 1999. p. 73. 
dignidade humana, à medida que se nega ao torturado a sua condição de pessoa, transmudando-o em mero objeto.

\section{CONCLUSÃO}

A humanidade sofreu em demasia com a tortura ao longo de sua história. A mudança de paradigma ocorreu com a perda inestimável de milhões de vidas através das duas Grandes Guerras Mundiais.

A consequência foi a criação de um sistema de Direitos Humanos que privilegiou a defesa do humano, não apenas do ser humano, mas também de sua dignidade.

Entretanto, a cultura e os hábitos são modificados instantaneamente, afinal, o acúmulo de anos de tortura é muito maior do que de prevenção das mesmas, por isso novos atos contra a humanidade surgiram.

E a resposta do sistema de Direitos Humanos foi a criação de um órgão autônomo com competência transnacional para julgar os crimes cometidos pelos governantes dos países signatários ao Tratado de Roma, nascia assim, o Tribunal Penal Internacional.

Tal ato demonstra que a humanidade está saturada das insanidades cometidas pelos grandes ditadores ao longo do tempo, pois já fora comprovado que apenas houve muitas e muitas perdas, sendo que a humanidade perece e ninguém é responsabilizado pelas atrocidades.

Entretanto, o Tribunal não é uma solução definitiva para a questão da tortura, e por uma questão muito simples, na verdade duas:

O Tribunal foi criado, em uma tentativa de ressarcir, ainda que minimamente, as perdas daqueles que deram a vida pela ambição de outrem, e também para impedir que atrocidades como as já presenciadas no passado, tornem a ocorrer.

Quando um Estado ratifica o Estatuto, concorda em aceitar a competência do Tribunal Penal Internacional para julgar os crimes enumerados no Estatuto de conformidade com o artigo 25. O Tribunal Penal Internacional pode exercer a sua competência em situações em que se verifique uma das seguintes condições: uma ou mais partes envolvidas são Estados Partes; o acusado é um cidadão nacional de um Estado Parte; o crime foi cometido no território de um Estado Parte. 
Além disso, o Estatuto define rigorosamente a competência do Tribunal Penal Internacional. Este Tribunal foi instituído com base no princípio da complementaridade, o que significa que só pode exercer a sua competência quando um tribunal nacional não puder ou não estiver disposto a fazê-lo verdadeiramente. Os casos serão canalizados em primeiro lugar para os tribunais nacionais.

O Tribunal Penal Internacional não foi de modo algum criado para substituir a autoridade dos tribunais nacionais. Mas pode haver situações em que o sistema judicial de um Estado entre em ruptura ou deixe de funcionar. Também pode dar-se o caso de haver governos que tolerem uma atrocidade ou inclusivamente participem nela ou de haver funcionários que se mostrem relutantes em instaurar um processo judicial contra alguém que esteja numa posição de grande poder ou autoridade.

Os dois únicos empecilhos para que o Tribunal consiga punir todos os grandes ditadores são que somente poderão ser julgados aqueles que praticarem atrocidades após a instituição do Estatuto de Roma, e que o Tribunal somente poderá julgar indivíduos de países que ratificaram o Tratado. O que torna, hoje, Estados Unidos, China e Israel imunes. Sendo assim, todos os casos de tortura já relatados no Iraque ficarão impunes.

O mais impressionante é ver o ex-presidente norte-americano dizer que não se arrepende da Guerra com o Iraque, e que apesar de não terem armas químicas (motivo da Guerra) os EUA estão muito mais seguros sem Saddam Hussein.

Mas a que preço? Matando milhares de iraquianos, com imagens mostrando cenas de torturas e extermínio de civis.

Até quando os cidadãos do mundo irão ter de presenciar a soberba de alguns governantes, que sob o pretexto de defenderem sua nação promovem crimes indiscriminados, ou criam verdadeiras armas de guerra, como Osama Bin Laden, cidadão treinado pelo próprio Estados Unidos É chegada a hora de se conferiam autonomia ao Tribunal Penal Internacional, que a vida humana seja, enfim, considerada mais importante que interesses políticos individuais.

O Tribunal Penal Internacional chega como uma solução para as atrocidades, e para não deixar a humanidade esquecer do horror que uma única pessoa pode provocar. 
Como afirmou o Ex-Secretário-Geral das Nações Unidas, Kofi Annan: "Esperamos que, ao punir os culpados, o TPI dê algum consolo às vítimas sobreviventes e às comunidades que foram visadas pelos seus atos. E, o que é mais importante, esperamos que dissuada futuros criminosos de guerra e contribua para que esteja mais perto o que dia em que nenhum governo, nenhum Estado, nenhuma junta e nenhum exército poderão violar impunemente os direitos humanos."

Sobre o comentário do Ex-Secretário-Geral temos que registrar que quando da nossa visita a Auschwitz, a primeira impressão foi visitar um daqueles parques temáticos norte-americanos, porque tudo estava tão organizado que parecia um cenário.

Infelizmente, à medida que as portas de cada uma das casas iam sendo abertas a realidade se mostra desnuda. Tudo permanece intacto. $\mathrm{O}$ depósito com óculos dos presos, membros artificiais e os sapatinhos das crianças.

Cenas como essas já demonstram uma tortura visual a qualquer espectador minimamente inteligente da história do lugar.

Impressionante passa a ser a visita das salas destinadas às execuções na câmara de gás, que por ironia, se localizam ao lado de um espaço reservado aos fuzilamentos.

Exatamente neste ponto que queríamos registrar o ápice máximo de uma demonstração de tortura. Não pelo muro ou pelo fuzilamento, que são coisas atrozes por si só, mas detrás deste existe uma piscina, para que os alemães se deleitassem ao som da desgraça da humanidade.

Que os cidadãos do mundo não se esqueçam disso, para que o extermínio em massa, as agruras não tornem a acontecer. Os Direitos Humanos criaram um construto sólido para evitar acontecimentos como os relatados acima, porém, somente terão eficácia se os próprios governantes modificarem seus atos de selvageria e demonstrações claras de poder.

De tal sorte que cabe também aos governantes da maioria dos países do globo respaldar o Tribunal Penal Internacional, que é o responsável pela proteção do que lhes é mais precioso: a própria população mundial.

A humanidade não pode mais conviver com seu autoflagelo. A frase de que poucos mortos significam a segurança dos demais não tem mais espaço na realidade dos Direitos Humanos de hoje. Toda e qualquer vida deve ser preservada, o humano é deveras importante para ser desper- 
diçado. E continuar a aceitar a perda de uma vida pode implicar em novos extermínios em massa, portanto, que a efetivação dos Direitos seja plena e que os infratores sejam devidamente responsabilizados, ai sim, neste momento a paz estará instaurada, sem a necessidade de nenhuma guerra ou demonstração de poder.

\section{REFERÊNCIAS BIBLIOGRÁFICAS:}

ALVES, José Augusto Lindgren. A arquitetura internacional dos direitos humanos. São Paulo: FTD, 1997.

ARENDT, Hannah. Responsabilidade e julgamento. Trad. Rosaura Eichenberg. São Paulo: Companhia das letras, 2004.

AUSCHWITZ ALPHABET, disponível em: <www.spectacle.org/695/ausch.html >. Acesso em 13 de junho de 2010.

AUSCHWITZ: PRODUCCIÓN INDUSTRIAL DE LA MUERTE, disponível em <www.ucabista.com.ve/vnews/display.v/ART/2005/04/01/424c1a3 c4b2e8>. Acesso em 11 de novembro de 2011.

BECCARIA, Cesare. Dos delitos e das penas. Trad. J. Cretella Jr. E Agnes Cretella. 2. ed. Ver. São Paulo: Revista dos Tribunais, 1999. BOBBIO, Norberto. A Era dos Direitos. Rio de Janeiro: Elsevier, 2004.

CHOUKR, Fauzi Hassan; Kai Ambos. Tribunal Penal Internacional. São Paulo: Editora Revista dos Tribunais, 2000.

COIMBRA, Mário. Tratamento do Injusto Penal da Tortura. São Paulo: Revista dos Tribunais, 2002.

COMPARATO, Fábio Konder. A afirmação histórica dos direitos humanos. São Paulo: Saraiva, 1999.

FOLEY, Conor. Combate à Tortura - Manual para Magistrados e Membros do Ministério Público. Reino Unido: Human Rights Centre, University of Essex, 2003.

FOLHA DE SÃO PAULO, caderno mundo, p. A13, publicado em 27 de janeiro de 2005.

FOLHA DE SÃO PAULO, caderno mundo, p. A13, publicado em 28 de janeiro de 2005.

FOLHA DE SÃO PAULO, caderno mundo, p. A10, publicado em 16 de fevereiro de 2006. 
GONÇALVES, Antonio Baptista. Código de defesa da humanidade. Minas Gerais: Universo Jurídico, in <http://www.uj.com.br>, publicado em 27 de agosto de 2004.

O fim da impunidade aos crimes dos ditadores. Minas Gerais: Revista de Direito Penal e ciências afins, coordenação Lélio Braga Calhau, $n^{\circ} 42$, in $<$ http://www.direitopenal.adv.br> publicado em 23 de julho de 2004.

GONZÁLES GONZÁLES, Rossana. El control internacional de la prohibicíon de la tortura y otros tratos o penas inhumanos y degradantes. Granada: Universidad de Granada, 1998.

Grande Enciclopédia Larousse Cultural. São Paulo: Nova Cultural, 1998, v. 12.

GRIMA LIZANDRA, Vicente. Los delitos de tortura y de tratos degradantes por funcionários públicos. Valencia: Tirant lo Blanch, 1998.

KANT, Immanuel. Fundamentação da metafísica dos costumes. Trad. Paulo Quintela. Lisboa: Edições 70, 2001.

ODALIA, Nilo. A liberdade como meta coletiva. IN PINSKY, Jaime \& PINSKY, Carla Bassanezi (org.). História da cidadania. 5 ed. São Paulo: Contexto, 2010.

O GLOBO, caderno mundo, p. 30, publicado em 28 de janeiro de 2005.

O GLOBO, segundo caderno, p. 6, publicado em 4 de fevereiro de 2005. MARCHA DA VIDA EM AUSCHWITZ REÚNE PÚBLICO RECORDE, fonte BBC Brasil, publicado em 5 de maio de 2005 às $14 \mathrm{~h} 03$.

MEMORIAL AND MUSEUM AUSCHWITZ-BIRKENAU, disponível em <http://www.auschwitzmuzeum.oswiecim.pl/html/eng/start/index.php>. Acesso em $12 \mathrm{de}$ maio de 2012.

MIRANDA, Pontes de. Democracia, liberdade, igualdade. Campinas: Bookseller, 2002.

PIOVESAN, Flávia. Direitos humanos e o direito constitucional internacional. 3 ed. São Paulo: Max Limonad, 1997.

PROTOCOLO FACULTATIVO À CONVENÇÃO DAS NAÇÕES UNIDAS CONTRA A TORTURA E OUTROS TRATAMENTOS OU PENAS CRUÉIS, DESUMANOS OU DEGRADANTES. Reimpressão - Brasília: Secretaria Especial dos Direitos Humanos, 2004. 
RODRIGUEZ MESA, Maria José. Tortura y otros delitos contra la integridad moral cometidos por funcionários públicos. Granada: Comares, 2000.

SANZ, Jesus Barquin. Los delitos de tortura y tratos inhumanos o degradantes. Madrid: Edersa, 1992.

REVISTA MUNDO MISSÃO, março de 2004, ano 11, nº 80. 